\title{
P-cadherin Antagonist PF-03732010
}

National Cancer Institute

\section{Source}

National Cancer Institute. P-cadherin Antagonist PF-03732010. NCI Thesaurus. Code C91723.

An agent that inhibits P-cadherin (cdh3), with potential antineoplastic activity. PF03732010 binds to and inhibits the activity of p-cadherin. Inhibition of the activity of $p$ cadherin may inhibit tumor cell invasion and proliferation in $\mathrm{p}$-cadherin expressing tumor cells. P-cadherin, a cell-surface protein and member of the cadherin family, is overexpressed in a variety of solid tumors, and plays a role in cell adhesion, motility, invasion and proliferation. 